\title{
Chromosome contribution to Andean Polyploid Species of Senecio (Asteraceae), from Argentina
}

\author{
Mariana G. López ${ }^{1}$ *, Arturo F. WulfF ${ }^{1,2}$ and Cecilia C. Xifreda ${ }^{3,4}$ \\ ${ }^{1}$ Laboratorio de Citogenética y Evolución, Departamento de Ciencias Biológicas, Facultad de Ciencias Exactas y Naturales, \\ Universidad de Buenos Aires. Intendente Güiraldes y Costanera Norte, 1428 Buenos Aires, Argentina. \\ 2 Member of the Carrera del Personal de Apoyo (CONICET). \\ ${ }^{3}$ Laboratorio de Etnobotánica y Botánica Aplicada, Facultad de Ciencias Naturales y Museo, Universidad Nacional de La \\ Plata. Paseo del Bosque s/n, 1900 La Plata, Argentina. \\ ${ }^{4}$ Member of the Carrera del Investigador Científico (CIC-PBA).
}

\begin{abstract}
Meiotic chromosome numbers were determined and observations of meiotic behavior were made in six species and two hybrid specimens of Senecio L. (Asteraceae).

Two different numbers were found: $2 n=4 \mathrm{x}=40$ in S. pogonias Cabr., S. ragonesei Cabr., S. sectilis Griseb. and S. viridis Phil. var. radiatus R. E. Fr. and $2 n=8 \mathrm{x}=80$ in S. subulatus D. Don. var. subulatus and in S. uspallatensis Hook. et Arn.; the latter showed the same chromosome number previously reported. The chromosome number of the hybrid individuals was $2 n=4 x=40$, being their putative parents $S$. ragonesei and $S$. sectilis. B chromosomes were found in some individuals of $S$. pogonias, S. sectilis, S. subulatus var. subulatus and S. uspallatensis.

Many meiotic irregularities such as bridges, fragments, laggard chromosomes, micronuclei and cellular fusion were observed. The results are analyzed in relation to the persistence and success of these polyploids, and the speciation mechanisms operating within this group are discussed.
\end{abstract}

Keywords: B chromosomes, cell fusion, cytogenetics, meiotic behavior, polyploidy, Senecio.

\section{INTRODUCTION}

Senecio L. is a cosmopolitan genus with about 270 species growing in Argentine; most of them are distributed in the Altoandina phytogeographic province (CABRERA and ZARDINI 1980). Taxonomically, the genus is very controversial because of problems with species identification (CABRERA 1949, 1978; CABRERA et al. 1999).

There is a great variation in chromosome number which ranges between $n=5$ to $n=c a .92$ (LAWRENCE 1980), being $n=20$ the modal number of the genus (BOLKHOVSKIKH et al. 1969).

Previous cytological information for Argentinean species has been restricted to the chromosome number of a few of them, being the most fre-

\footnotetext{
* Corresponding author: fax ++54 011 4576-3384; e-mail: magalo@bg.fcen.uba.ar
}

quent ones $n=20$ and $n=40$ (HUNZIKER et al. 1985, 1989; WulfF 1994, 1998; WulfF et al. 1996).

Polyploidy is widely distributed in the genus and different levels have been described (LAWRENCE 1980). The basic number generally accepted is $\mathrm{x}=10$ (LAWRENCE 1985; ORNDUFF et al. 1963).

In order to bring a better knowledge of them, cytotaxonomical studies have been performed in Argentinean species of Senecio (LóPEZ 2001). Our results on chromosome number and meiotic behaviour are discussed in relation to the speciation model in the group.

\section{MATERIALS AND METHODS}

The studied materials and procedences are summarized in Table 1. 
Table 1 - Chromosome numbers and meiotic configurations of six species and two hybrids of Senecio. The numbers between brackets indicate number of individuals and number of cells analyzed.

\begin{tabular}{|c|c|c|c|c|}
\hline Taxa & $2 n$ & Fig. & Meiotic configurations & Procedence and Vouchers \\
\hline $\begin{array}{l}\text { S. pogonias Cabr.* } \\
(2,28)\end{array}$ & $\begin{array}{c}40 \\
40+1 \mathrm{~B}\end{array}$ & $1 \mathrm{~A}-\mathrm{C}$ & $\begin{array}{c}20 \mathrm{II}(82,14 \%) \\
18 \mathrm{II}+1 \mathrm{IV}(17,86 \%)\end{array}$ & $\begin{array}{l}\text { San Juan, Iglesias, Qda. } \\
\text { Arrequitín } 3180 \text { msm. } \\
\text { TST, RK et AFW 19,23. }\end{array}$ \\
\hline $\begin{array}{l}\text { S. sectilis Griseb.* } \\
(2,27)\end{array}$ & $\begin{array}{c}40 \\
40+1 \mathrm{~B}\end{array}$ & & $\begin{array}{c}20 \mathrm{II}(81,48 \%) \\
18 \mathrm{II}+1 \mathrm{IV}(7,42 \%) \\
17 \mathrm{II}+1 \mathrm{VI}(3,7 \%) \\
16 \mathrm{II}+2 \mathrm{IV}(3,7 \%) \\
16 \mathrm{II}+1 \mathrm{VIII}(3,7 \%)\end{array}$ & $\begin{array}{l}\text { San Juan, Angaco, Estancia } \\
\text { Don Carmelo } 2950 \text { msm. } \\
\text { TST, RK et AFW 4, } 6 .\end{array}$ \\
\hline$(3,24)$ & $\begin{array}{c}40 \\
40+5 B\end{array}$ & & $\begin{array}{c}20 \mathrm{II}(87,15 \%) \\
18 \mathrm{II}+1 \mathrm{IV}(12,85 \%)\end{array}$ & $\begin{array}{l}\text { San Juan, Ullún, Sa. Nevada } \\
\text { y del Tigre } 3146-3350 \text { msm. } \\
\text { TST, RK et AFW } 11,12,14 .\end{array}$ \\
\hline
\end{tabular}

\begin{tabular}{|c|c|c|c|c|}
\hline $\begin{array}{l}\text { S. ragonesei Cabr.* } \\
(1,13)\end{array}$ & 40 & $1 \mathrm{D}$ & $\begin{array}{c}20 \mathrm{II}(92,3 \%) \\
18 \mathrm{II}+1 \mathrm{IV}(7,7 \%)\end{array}$ & $\begin{array}{l}\text { San Juan, Angaco, Sa. } \\
\text { Pie de Palo } 2950 \text { msm. } \\
\text { TST, RK et AFW } 7 .\end{array}$ \\
\hline
\end{tabular}

S. sectilis $x$ ragonesei

$(2,30)$

40

$\begin{array}{lc} & 20 \mathrm{II}(73,34 \%) \\ 1 \mathrm{H}-\mathrm{L} & 19 \mathrm{II}+2 \mathrm{I}(23,33 \%)\end{array}$

San Juan, Angaco, Sa.

$18 \mathrm{II}+1 \mathrm{IV}(3,33 \%)$

Pie de Palo $3000 \mathrm{msm}$.

TST, RK et AFW 2, 5.

S. viridis Phil. var. radiatus

R.E.Fr.*

$40 \quad 1$ F-G

$20 \mathrm{II}(70,27 \%)$

$18 \mathrm{II}+1 \mathrm{IV}(21,63 \%)$

$19 \mathrm{II}+2 \mathrm{I}(5,4 \%)$

$17 \mathrm{II}+1 \mathrm{VI}(2,7 \%)$

$38 \mathrm{II}+1 \mathrm{IV}(50 \%)$

$40 \mathrm{II}(16,7 \%)$

S. subulatus D. Don var.

subulatus*

$(1,18)$

$80+2 B$

2 A-D

$36 \mathrm{II}+2 \mathrm{IV}(11,1 \%)$

$37 \mathrm{II}+1 \mathrm{VI}(11,1 \%)$

$35 \mathrm{II}+1 \mathrm{VI}+1 \mathrm{III}+1 \mathrm{I}(5,5 \%)$

$35 \mathrm{II}+1 \mathrm{VIII}+2 \mathrm{I}(5,5 \%)$

S. uspallatensis Hok. et Arn.

$(3,20)$

80

$80+1 \mathrm{~B}$

$80+4 \mathrm{~B}$

80

$$
\begin{gathered}
33 \mathrm{II}+1 \mathrm{VI}+2 \mathrm{IV}(20 \%) \\
38 \mathrm{II}+1 \mathrm{IV}(10 \%) \\
36 \mathrm{II}+2 \mathrm{IV}(10 \%) \\
34 \mathrm{II}+3 \mathrm{IV}(10 \%) \\
32 \mathrm{II}+4 \mathrm{IV}(10 \%) \\
35 \mathrm{II}+1 \mathrm{VI}+1 \mathrm{IV}(10 \%) \\
32 \mathrm{II}+2 \mathrm{IV}+1 \mathrm{VIII}(10 \%) \\
31 \mathrm{II}+1 \mathrm{IV}+1 \mathrm{VI}+1 \mathrm{VIII}(10 \%) \\
29 \mathrm{II}+3 \mathrm{IV}+1 \mathrm{X}(10 \%)
\end{gathered}
$$

Mendoza, Luján de Cuyo, Potrerillos $1400 \mathrm{msm}$.

$$
\text { AFW } 702 .
$$

San Juan, Angaco, gote Corralitos $3040 \mathrm{msm}$. TST, RK et AFW 1, 3.

2 E-H

$(2,26)$

$$
\begin{gathered}
38 \mathrm{II}+1 \mathrm{IV}(48,2 \%) \\
40 \mathrm{II}(22,2 \%) \\
36 \mathrm{II}+2 \mathrm{IV}(18,5 \%) \\
34 \mathrm{II}+3 \mathrm{IV}(3,7 \%) \\
33 \mathrm{II}+1 \mathrm{III}+2 \mathrm{IV}+3 \mathrm{I}(3,7 \%) \\
32 \mathrm{II}+1 \mathrm{IV}+2 \mathrm{VI}(3,7 \%)
\end{gathered}
$$

Mendoza, Las Heras, Villavicencio y Paramillo de Uspallata 2200-2700 msm. AFW 766, 767, 771.

L TST, RK et AFW = T.S. Tombesi, R. Kiesling et A.F. Wulff; AFW = A.F. Wulff.

* First record for chromosome number. 
Voucher specimens are deposited in the Herbarium of the Facultad de Ciencias Exactas y Naturales, Buenos Aires University (BAFC) and in the Herbarium of Institute Darwinion (SI). The identification of the material was performed by Mariana G. López and Cecilia C. Xifreda.

Meiotic studies were undertaken in young inflorescences previously fixed in 6:3:1 (absolute ethanol: chloroform:glacial acetic acid) or modified Newcomer's solution (HUNZIKER 1966) and stored in alcohol $70 \%$. The squash of the anthers was made in a drop of acetic haematoxylin using ferric citrate $(1 \%)$ as mordant (NuÑEZ 1968). Pollen stainability was determined with ALEXANDER's staining (1969). Different chromosome numbers indexes were checked.

\section{RESULTS}

\section{Chromosome numbers}

Two chromosome numbers were found: $2 n=40$ and $2 n=80$. The number corresponding to each species is indicated in Table 1 .

The two individuals from hybrid origin showed $2 n=40$. According to their morphology the putative parents of these hybrids should be $S$. sectilis and $S$. ragonesei, but it is not known which the female and male parents was (LÓPEZ et al. in preparation).

\section{Meiotic behavior}

Meiotic configurations of each species are showed in Table 1. S. pogonias and S. ragonesei showed the most regular meiotic configurations (20 II or $18 \mathrm{II}+1 \mathrm{IV}$, Table 1) (Fig. 1A, D). However, cell fusion was observed in $S$. pogonias at diplotene, diakinesis (Fig. 1B), metaphase I and telophase II (Fig. 1C). Other irregularities observed were: univalents out of plate at metaphase I and laggard chromosomes at anaphase II.

In $S$. sectilis the most frequent meiotic configuration was 20 II (Fig. 1F) but other ones were detected although in low frequency (see Table 1). The individual with $2 n=40+5 \mathrm{~B}$ (specimen no. 11) always presented 20 II at metaphase I and a regular meiotic behavior. At telophase II micronuclei were observed. Two individuals (specimens no. 4 and 6) also showed cell fusion (Fig. 1E).

In S. viridis var. radiatus, 20 II was the most frequent meiotic configuration, but univalents (I), quadrivalents (IV) and hexavalents (VI) were also observed (see Table 1, Fig. 1G).
In the two hybrid individuals the most common meiotic configuration at diakinesis was $20 \mathrm{II}$ followed by $19 \mathrm{II}+2 \mathrm{I}$ (Fig. 1H), the majority of which were open bivalents. However, at metaphase I from 1 up to 9 univalents (I) out of plate were observed (Fig. 1I). Moreover, a bridge and a fragment were found at anaphase I (Fig. 1J), and also a bridge and laggard chromosomes at anaphase II (Fig. 1K), telophase II with micronuclei, and pentads were observed (Fig. 1L).

S. subulatus var. subulatus showed a great diversity of meiotic configurations (Table 1). At metaphase I certain degree of secondary association among four bivalents was observed (Fig. 2A, B). At this phase up to five univalents out of plate and two $\mathrm{B}$ chromosomes were found (Fig. 2C). At anaphase I a bridge and a fragment were detected (Fig. 2D), as well as laggard chromosomes at both anaphases, and tetrads with micronuclei.

The five analyzed individuals of S.uspallatensis showed the most variable chromosome configurations (Table 1). Different kinds of multivalents were found both at diakinesis and metaphase I (Fig. 2E, F, G). Univalents and bivalents out of plate at metaphase I, laggard chromosomes at both anaphases and micronuclei at telophase II were observed. Cell fusion occurred at both diakinesis and telophase II (Fig. 2H).

Due to their small size, B chromosomes could only be detected in a few cells and always as univalents; therefore they were not included in the analysis of meiotic configurations.

\section{Pollen stainability}

In all the analyzed species pollen stainability was high. However, a great variability in grain size was observed, mostly in those species which presented cell fusion (Fig. 3A, B).

The two hybrid individuals showed different results. One of them (specimen no. 2) presented a notably low pollen stainability $(40,6 \%)$ and a great variation in pollen size (Fig. 3C, D); while the other, conversely, (specimen no. 5) showed regular pollen grain size and high stainability (94\%).

\section{DISCUSSION}

\section{Chromosome numbers}

This is the first report for S. pogonias, $S$. ragonesei, $S$. sectilis, $S$. viridis var. radiatus and S. subulatus var. subulatus. The number previ- 

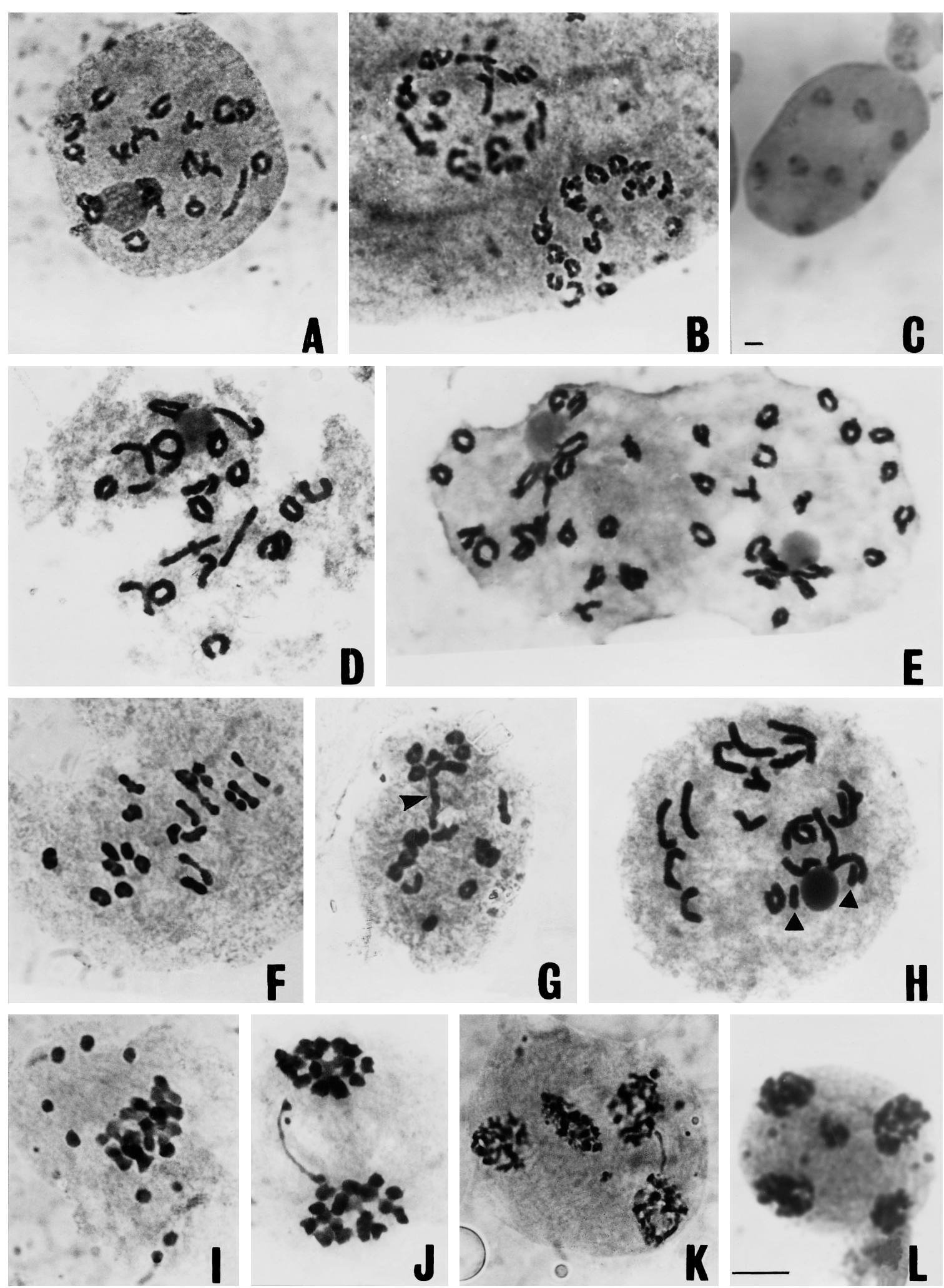

Fig. 1 - Meiotic chromosomes. A-C: S. pogonias; A, diakinesis (20 II); B, fusion of two diakinesis cells; C, octad (scale $100 \mathrm{~mm}$ ); D: S. ragonesei, diakinesis (20 II); E: S. sectilis, fusion of two diakinesis cells (20 II); F-G: S. viridis var. radiatus; F, metaphase I (20 II); G, diakinesis showing an hexavalent; H-L: S. sectilis x S. ragonesei; H, diakinesis (19 II + 2 I); I, metaphase I with 9 univalents; J, late anaphase I with bridge and fragment; K, telophase II with bridge; L, pentad. Arrow head: hexavalent (VI), full triangles: univalents (I). Scale $10 \mu \mathrm{m}$. 
ously reported for $S$. uspallatensis is confirmed (COVAS and SCHNACK 1947; HUNZIKER et al. 1989).

Secondary association and basic chromosome number

The basic number of Senecio is a controversial subject. The most accepted basic numbers are $\mathrm{x}=5$ (TURNER and LEWIS 1965) and $\mathrm{x}=10$ (ORNDUFF et al. 1963; LAWRENCE 1985). The observation of secondary associations has allowed to determine the basic numbers in the genus Eulophia (PogGIO et al. 1986), Amaranthus (GREIZERSTEIN and Poggio 1992), Zea (Molina and NARANJo 1987) and Anredera (ARGIMÓN et al. 1999). Therefore, the detection of secondary associations of up to four bivalentes in $S$. subulatus var. subulatus $(2 n=80)$ support the hypothesis of $\mathrm{x}=10$. The species analyzed in the present work belong to two different ploidy levels: tetraploidy and octoploidy.

\section{Meiotic configurations and probable polyploid origin}

The high frequency of bivalents in $S$. ragonesei, S. pogonias, S. sectilis and S. viridis var. radiatus suggests an allotetraploid origin, and the sporadic presence of a quadrivalent in the two former could be explained by allosyndetic or heterogenomic pairing (GRANT 1989). The higher number of quadrivalents observed in $S$. sectilis should be related to a higher chiasmata frequency (LÓPEZ 2001). However, the individual specimen no. 11, which presented $5 \mathrm{~B}$ chromosomes, showed always twenty bivalents; this fact suggests that the $\mathrm{B}$ chromosomes favor homologous pairing.

Moreover, the octoploid species $S$. uspallatensis and $S$. subulatus which also showed a high frequency of bivalents and few multivalents would have an allopolyploid origin, probably of the segmentary type.

Within each ploidy level, multivalents with more chromosomes as expected such as hexavalents and octovalents in tetraploid species (S.sectilis and $S$. viridis var. radiatus) or decavalents in octoploid species (S. uspallatensis and S. subulatus var. subulatus) would be the consequence of intergenomic translocations (JACKSON and CASEY 1980; SOLTIS and SOLTIS 1993, 1999).

The analysis of the meiotic configurations give some clues about the origin of polyploids. However, in agreement with QU et al. (1998) and SOLTIS and SOLTIS (1999), molecular studies should be performed in order to convalidate the hypothesis proposed.

\section{Meiotic irregularities}

The presence of univalents or bivalents out of plate at metaphase I, would be the consequence of extreme climatic variations that occur in the environment these species inhabit daily. In both cases, chromosomes could lag at anaphase I, remaining separated until anaphase II and giving rise to micronuclei.

Other meiotic irregularities such as bridges and fragments at anaphase I, and bridges at anaphase II, are cytological consequences of heterozygosity for a paracentric inversion; this chromosome rearrangement could have taken place after the appearance of the polyploid.

In the hybrids, the higher number of univalents at metaphase I than at diakinesis could be explained by a precocious disjunction of bivalents. This fact, together with the observation of a low chiasma frequency, suggests a reduced homeology between the parental genomes, as it has been described in Elytrigia (HUNZIKER and FERRARI 1986).

\section{Cell fusion and pollen size differences}

Cell fusion (SPIES 1993), presence of B chromosomes (SHAH 1963, 1964) and different abnormalities occurring during microsporogenesis (RAMANNA 1979; BRETAGNOLLE and THOMPSON 1995; RIM and BEUSELINCK 1996) give rise to non reduced gametes and, hence, to $2 n$ pollen; this pollen is usually larger in size than $n$ pollen and size differences can even be detected at the optic microscope (MACEIRA et al. 1992).

Since cell fusion, B chromosomes and large pollen grains have been observed in some species here analyzed, it can be concluded that they should produce $2 n$ or non-reduced gametes. Furthermore, size differences within $n$ pollen could be due to the meiotic irregularities already described.

\section{CONCLUSION}

The finding of hybridization within the small group of species here analyzed, is reflecting a general feature of the genus (BECK 1992; OBERPRIELER 1994; HODÁlOVÁ and VALACHOVIC 1996; HODÁLOVÁ 1999). The recurrent origin of polyploid species from genotipically different populations is also frequent (ASHTON and ABBOTT 1992) and it is also common in other groups such as Tragopogon (Asteraceae) and Dra- 

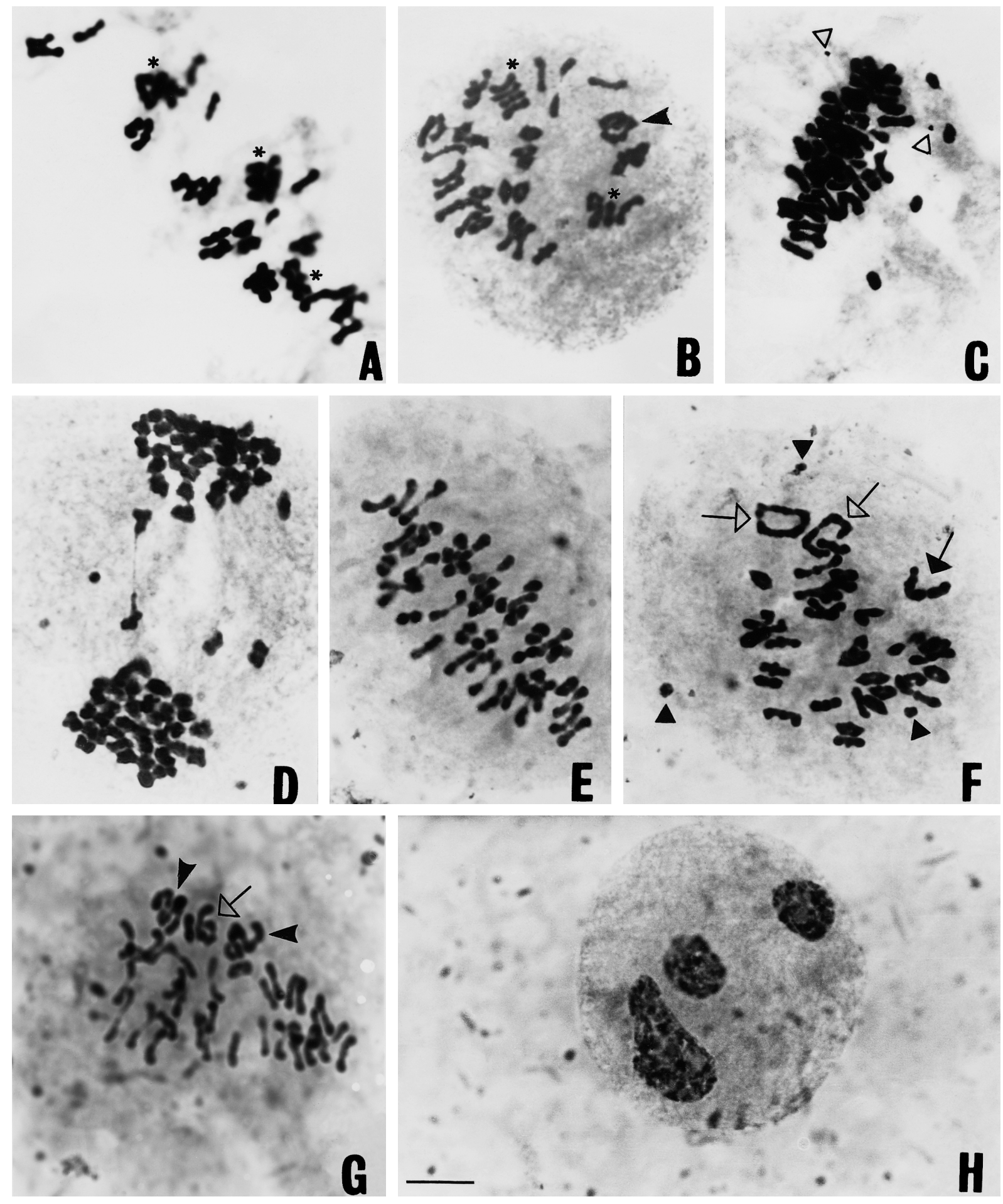

Fig. 2 - Meiotic chromosomes A-D: S. subulatus var. subulatus, A-B, metaphase I, showing secondary chromosome association; C, metaphase I with 4 univalents out of plate and 2 B chromosomes; D, anaphase I with a bridge and a fragment; E-H: S.uspallatensis; E, metaphase I (40 II); F, prometaphase I (33 II + 1III + 2 IV + 3 I); G, prometaphase I (32 II + 1 IV + 2 VI); $\mathrm{H}$, telophase II with nuclear fusion. Asterisks: secondary association of bivalents, arrow head: hexavalents (VI), empty triangles: B chromosomes, empty arrows: quadrivalents (IV), full arrows: trivalents (III), full triangles: univalents (I). Scale $10 \mu \mathrm{m}$. 
ba (Brassicaceae) (Soltis and Soltis 1993, 1999).

The occurrence of large genomic rearrangements within polyploids (JACKSON and CASEY 1980; SOLTIS and SOLTIS 1993, 1999) together with the processes previously described, would originate a complex of genotypes and morphotypes, which reflects in the different taxa as a morphological continuum (SOLTIS and SOLTIS 1999). This will explain the difficulties that arise when trying to identify different species, as well as the great taxonomic complexity of the genus Senecio.

Within this polyploid complex, the heterozygosity of the individuals should be increased, and new genic combinations, some of them more adaptative, would appear (STEBBINS 1980;
THOMPSON and LuMARET 1992); this would explain the success and persistence of these polyploids in nature. The appearence of these new combinations would also favor the reproductive isolation at genomic (pre-zygotic) level and therefore, the origin of new specific identities. Summarizing, one of the principal speciogenic processes operating within the group would be polyploidy with all its consequences.

Acknowledgements - This research was supported by UBA TW057. The authors thank Dr. Juan H. Hunziker, Dra. Alba G. Papeschi and Dra. Mariel Sanso for critical review of manuscript. A.F. Wulff thanks Dr. Roberto Kiesling for collection trip.

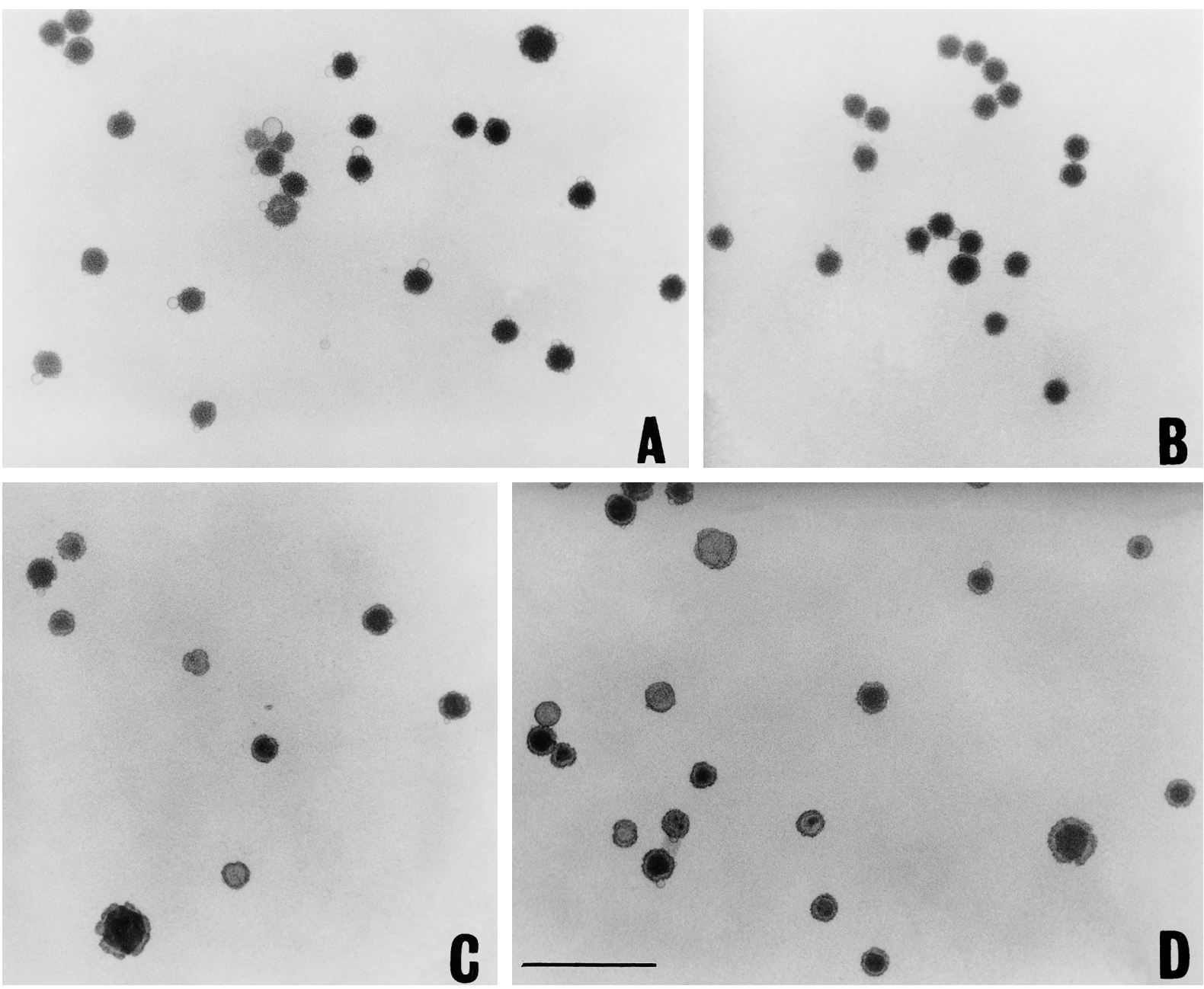

Fig. 3 - Pollen stainability A-B: S. uspallatensis, showing high stainability and differences in grain pollen size; C-D: S. sectilis $\mathrm{x} S$. ragonesei (TST et al. 2), showing low stainability and high differences in grain pollen size. Scale $100 \mu \mathrm{m}$. 


\section{REFERENCES}

ALEXANDER M.P., 1969 - Differential staining of aborted and nonaborted pollen. Stain Technology, 44: 117-122.

Argimón S., WulfF A.F. and Xifreda C.C., 1999 - Chromosome association and basic number in Anredera krapovickasii (Basellaceae). Caryologia, 52: 203-206.

AsHTON P.A. and АввотT R.J., 1992 - Multiple origins and genetic diversity in the newly arisen allopolyploid species, Senecio cambrensis Rosser (Compositae). Heredity, 68: 25-32.

Beck E., Scheibe R., Schlutter I. and Sauer W., 1992 - Senecio x saundersii Sauer and Beck (Asteraceae), an intermediate bybrid between S. keniodendron and S. keniensis of Mt. Kenya. Phyton, 32: 9-37.

BolKhOVSKIKH Z., Grif V., MatvejeVA O. and ZAKHARYYEVA O., 1969 - Chromosome numbers of flowering plants. Leningrad: Academy of Science USSR. Reimpr. P. Koeltz Science Pebl. West Germany, 1974.

BRETAgNolle F. and Thompson J. D., 1995 - Gametes with the somatic chromosome number: mechanism of their formation and role in the evolution of autopolyploid plants. New Phytology, 129: 1-22.

CABrera A.L., 1949 - El género Senecio en Chile. Lilloa, 15: 27-501.

-, 1978 - Compuestas. Flora de la Provincia de Jujuy. República Argentina. Colección Científica del INTA Tomo XIII, Parte X.

Cabrera A.L., Freire S.E. and Ariza Espinar L., 1999 - Flora Fanerogámica Argentina 62. Asteraceae parte XIII. 1 vol. 188 pp. ProFlora (CONICET).

CABRERA A.L. and ZARDini E.M., 1980 - Sinopsis preliminar de las especies argentinas del género Senecio (Compositae). Darwiniana, 22: 427-492.

Covas G. and Schnack B., 1947 - Estudios cariológicos en Antófitas. II parte. Revista Argentina de Agronomía, 14: 224-231.

Grant V.S., 1989 - Especiación Vegetal. México, Limusa.

Greizerstein E.J. and Poggio L., 1992 - Estudios citogenéticos de seis hibridos interespecíficos de Amaranthus (Amaranthaceae). Darwiniana, 31: 159-165.

HodÁlová I. and Valachovic M., 1996 - Sympatric populations of Senecio ovatus subsp. ovatus, S. germanicus subsp. germanicus (Compositae) and their bybrid in the Carpathians and the adjacent part of Pannonia. Flora, 191: 291-302.

HodÁLOVÁ I., 1999 - Multivariate analysis of the Senecio nemorensis group (Compositae) in the
Carpathians with a new species from the East Carpatbians. Folia Geobotanica, 34: 321-335.

HUNZIKER J.H., 1966 - Números cromosómicos y cariotipos de varias especies sudamericanas de Agropyron y Elymus (Gramineae). Kurtziana, 3: 151-156.

HunZiKer J.H. and FerRARI M.R., 1986 - Citogenética de híbridos interespecíficos y electroforesis de proteinas seminales de cuatro especies sudamericanas de Elytrigia (Gramineae). Darwiniana, 27: 191-206.

Hunziker J.H., WulfF A.F., Xifreda C. and EsCOBAR A., 1989 - Estudios cariológicos en Compositae V. Darwiniana, 29: 25-39.

HunZiKer J.H., XifredA C. and WulfF A.F., 1985 - Estudios cromosómicos en Angiospermas de Sudamérica. Darwiniana, 26: 7-14.

JACKSON R.C. and CASEY J., 1980 - Cytogenetics of polyploids. In: W. H. Lewis (ed.), "Polyploidy", pp. 17-42. Plenum Press, New York, NY.

LAWRENCE M.E., 1980 - Senecio L. (Asteraceae) in Australia: chromosome numbers and the ocurrence of polyploidy. Austr. J. Bot., 28: 151-165.

-, 1985 - Senecio L.(Asteraceae) in Australia: recombination systems of a polyploid series. Austr. J. Bot., 33: 209-219.

LÓPEZ M.G., 2001 - Estudios citotaxonómicos en especies altoandinas de Senecio L. (Asteraceae). Thesis. Facultad de Ciencias Exactas y Naturales. Universidad de Buenos Aires.

Maceira N.O., De HaAn A.A., Lumaret R., BILlen M. and DellaY J., 1992 - Production of $2 n$ gametes in diploid subspecies of Dactylis glomerata L. 1. Occurrence and frequency of $2 n$ pollen. Ann. Bot., 69: 335-343.

Molina M. DE C. and NARANJo C.A., 1987 - Cytogenetic studies in the genus Zea. 1. Evidence of five as the basic chromosome number. Theor. Appl. Genet., 73: 542-550.

NuÑEZ O., 1968 - An acetic-hematoxilin squash method for small chromosomes. Caryologia, 21: 115-119.

OBERPRIELER CH., 1994 - Die Senecio nemorensisGrouppe (Compositae, Senecioneae) in Bayern. Ber. Bayer. Bot. Gesell., 64: 7-54.

OrNDUFF R., RAVEN P.H., KYHOS D.W. and KRUCKEBERG A.R., 1963 - Chromosome numbers in Compositae III. Senecioneae. Amer. J. Bot., 50: 131-139.

Poggio L., Naranjo C.A. and Jones K., 1986 The chromosomes of Orchids IX. Eulophia. Kew Bulletin, 41: 45-49.

Qu L., HANCOCK J.F. and WHALlON J.H., 1998 Evolution in an autopolyploid group displaying predominantly bivalent pairing at meiosis: genomic similarity of diploid Vaccinium darrowi and 
autotetraploid V. corymbosum (Ericaceae). Amer. J. Bot., 85: 698-703.

RAMANNA M.S., 1979 - A re-examination of the mechanisms of $2 n$ gamete formation in potato and its implications of breeding. Euphytica, 28: 535-561.

RiM Y.W. and BEUSELINCK P.R., 1996 - Cytology of $2 n$ pollen formation and pollen morphology in diploid Lotus tenuis (Fabaceae). Amer. J. Bot., 83: 1057-1062.

SHAH S.S., 1963 - Studies on supernumerary chromosomes in the genus Dactylis. Chromosoma (Berl.), 14: 162-165.

-, 1964 - Studies on a tetraploid, a tetrasomic triploid and a trisomic plant of Dactylis glomerata. Chromosoma (Berl.), 15: 469-477.

SolTiS D.E. and SOLTis P.S., 1993 - Molecular data and the dynamic nature of polyploidy. Critical Reviews in Plant Sciences, 12: 243-273.

-, 1999 - Polyploidy: recurrent formation and genome evolution. Trends in Ecology and Evolution, 14:348-352.

SPIES J.J., 1993 - Cell fusion: a putative mechanism of polyploidy. 27th. International Congress of
Genetic. Birmingham. United Kingdom. Citogenetic Abstracts, 23: 134.

SteBBIns G.L., 1980 - Unsolved problems and prospects. In: W.H. Lewis (ed.), Polyploidy, pp. 17-42. Plenum Press, New York, NY.

THOMPSON J.D. and LUMARET R., 1992 - The evolutionary dynamics of polyploid plants: origins, establishment and persistence. Trends in Ecology and Evolution, 7: 302-307.

TURNER B.L. and LEWIS W.H., 1965 - Chromosome numbers in the Compositae. IX. African species. Journal of South Africa Botany, 31: 207-217.

WULFF A.F., 1994 - Estudios citogenéticos y evolutivos en Compuestas Sudamericanas. Tesis de Doctorado de la Facultad de Ciencias Exactas y Naturales. U.B.A.

-, 1998 - Estudios cariológicos en Asteraceae VIII. Darwiniana, 35: 37-43.

WulfF A.F., Hunziker J.H. and Escobar A., 1996 - Estudios cariológicos en Compositae VII. Darwiniana, 34: 213-231.

Received September 6, 2001; accepted November 14, 2001 